\title{
The Competence Approach as a Methodological Tool for Shaping the Professional Competence of Future Music Teachers
}

\author{
Alla V. Kozyr \\ National Pedagogical Dragomanov University \\ Vasyl I. Fedoryshyn \\ National Pedagogical Dragomanov University \\ Olena V. Khoruzha \\ National Pedagogical Dragomanov University \\ Larysa V. Chyncheva \\ National Pedagogical Dragomanov University \\ Oksana P. Gusachenko \\ National Pedagogical Dragomanov University
}

The article considers the role, importance and features of the competence approach as strong trend in the development of art education in the context of global integration and globalisation trends. The key properties of professional competency of a future art teacher are characterised; the significance of the system of thinking actions and operations as the basic foundation for its development is established. The specificity of methodological support for the teaching of art disciplines, aimed at using the maximum number of mental operations, is described. The conducted research allowed generalising the definition of professional competency of future art teachers as an integrated qualitative characteristic of an art teacher, which is a complex of knowledge, abilities and skills acquired as a result of professional art training, selfstudy, own teaching and performing experience in the areas of teaching art disciplines, art history, pedagogy, psychology, etc., and pedagogical and artistic communication, the ability to operate freely with certain knowledge and skills and to apply them effectively in the course of practical professional activities.

Keywords: art education, professional teacher training, mental actions and operations, modern pedagogical trends, quality of education

\section{INTRODUCTION}

Today's reality of increased public attention to the quality and effectiveness of the national educational system in Ukraine and, in particular, to the problems of art education, generates a constant scientific interest not just in the development of future teachers, teachers of artistic disciplines professional competency, but 
in the permanent improvement of its level in graduates of art teacher training universities. This is why the transfer of art education at all levels to the competence-based approach has become a priority, and the competence-based approach itself has been in the trend of applying methodological approaches to develop scientific-theoretical foundations for scientific research in art pedagogy for more than twenty years. This long-term trend of competency-based art education is due to other sustainable modern trends inherent in the global information society - trends of accelerated information exchange, in particular, digital technologies, scientific achievements, trends of relatively accelerated socio-economic processes, increased mobility of people, etc. It is the high level of competence of teachers for modern developed society that determines both the professional management of the quality of education of the younger generation and the development of its spiritual culture, intellectual potential, and further competitiveness of this generation in the global world community as a guarantee of the implementation of the success of the whole state in the conditions of integration of national economies into the globalised world space.

The key role in ensuring the priority position of the competency approach in the educational processes of Ukraine has been played by the comprehensively developed legal framework, in particular such regulatory documents as the Law of Ukraine "Higher Education Act", which serves as a pointer for the development of higher art education institutions, as well as the Concept "New Ukrainian School", which determines the directions of art education in secondary education institutions. The above-mentioned regulations clearly define strategic vectors of educational policy for structural and content modernisation of art education system at all levels based on competency-based approach, involvement of information and communication technologies, as well as systematic monitoring of the results and quality of educational processes. The strategic vectors of educational policy, justified in the above-mentioned legal and regulatory documents, enable the development of Ukrainian society as an open information society, oriented towards satisfying the spiritual and material needs of citizens, each of whom has the opportunity to acquire, accumulate and develop their knowledge resources, improve personal and professional qualities, gain free access to any information, and to use this information effectively to realise their own intellectual and creative potential in the process of competent production of professional activities.

The development of professional competency of future teachers, teachers of artistic disciplines is actualised by targeting the process of professional art training of young professionals to maximise their mastery of the set of subject competences, occurs, on the one hand, based on fundamentalisation of educational processes, as close to the real conditions of future professional activity, and on the other hand, by developing the intellectual and creative potential of young people through the permanent introduction of innovative technologies as well as their harmonious integration with the pedagogical tools in art education repeatedly checked and proven over decades. The specificity of modern requirements for development of professional competences of future teachers, teachers of art disciplines in institutions of higher art education is, in the authors' opinion, in the plane of orientation of this process not only to the ways and forms of implementation of the indicated strategic vectors of educational policy (structural and content modernisation of art education based on competence approach and its monitoring, informatisation of the professional training process, etc.), but also on purposeful development of a creative personality of a teacher-artist with a high level of creative intellectual capabilities, proper level of intelligence quotient, formed competences in the field of musical performance, pedagogical communication, methodology of musical training and education, etc. Thus, the focus of professional training of students of art pedagogical universities on the development of professional competency as an important factor in managing the quality of art education actualises and intensifies the process of its improvement in the context of competence approach, promotes the provision of art education with new content, meaning and dimensions.

\section{AN ANALYSIS OF PREVIOUS PAPERS ON THE RESEARCH TOPIC}

The role and importance of the competency-based approach for the development of art education can hardly be exaggerated, as it is the key approach today in the context of global integration and globalisation trends, in particular towards European education system harmonisation. As an example, the Council of Cultural Cooperation of the Council of Europe defines the competency-based approach as one of the basic 
principles for the development of the European educational space, based on the definition of certain key competences. Consideration of the concepts of "competency" and "competence", underlying the competency-based approach, suggests that there are two ways of interpreting their essence - identification and differentiation. The direction of the identification of these definitions is provided in the Dictionary of the European Training Foundation. According to this document, the term "competence" includes the ability to: perform work well, effectively; meet the necessary requirements for employment; and perform a specific job function. At the same time, this glossary notes that "... the term "competency" is used with the same meanings. The competency is usually applied in a descriptive way". In other words, the above-mentioned interpretation of both concepts provides for the application of the competency-based approach directly in the context of practical professional activity.

The opposite direction on differentiated interpretation of the definitions of "competency" and "competence" is based on the concept of R. White, who explains the definition of competence in the context of motivation of an individual, taking it out of purely practical-activity sphere. This scientific position was supported and creatively developed by N. Khomsky, who actually laid the foundation for the American competence-based education concept of CBE (competence-based education), which is based on the competency-based approach. The scientist clearly defined the definition of "competence", which he linked to knowledge and its application in practice, suggesting to rely on the concept of A. von Humboldt. In using the term "application", N. Khomsky insisted on the connection to personal psychological entities such as thinking, psychological responsiveness, empirical experience, etc. A further contribution to the development of the competence approach methodology was made by D. Raven, who insisted on the complex and multi-component structure of personal competency, arguing for abstractness and relative independence of its components, as well as their belonging to both emotional and cognitive spheres.

J. Delors also transformed the methodology of the competency-based approach in educational processes and deepened the understanding of the competency concept, was voiced by him in the report of the UNESCO International Commission on Education for the 21st Century "Education: The Hidden Treasure". The author pointed out the four main directions of modern competency-based education (learning to know, learning to do, learning to live together, learning to be), according to which a person should acquire four global competencies. The cognitive orientation (learning to know) is related to the acquisition of cognitive competency. The development of professional competency is linked to the professional direction (learning to do). The acquisition of communicative competency is linked to the direction of intelligent and mutually beneficial coexistence and communication. The fourth area (learning to live) correlates with the development of generalised life skills. The development of professional competency of future teachers, teachers of art disciplines is in the plane of the second direction of the competence approach, which involves "learning to do in order to acquire not only a professional qualification, but also in a broader sense the competency to cope with various multiple situations and work in a group".

The differentiated interpretation of the main concepts of the competency approach - competency and competence - also corresponds to the scientific position of W. Hutmacher, who argued that the concept "competence" has a practical-activational content, while the concept "competency" is more comprehensive, thus, it also contains personal components. Thus, the analysis of the development of the competency-based approach and the content of its key understandings allows asserting the feasibility of differentiating and integrating the notions of "competence" and "competency". For example, broader personal and professional characteristics such as "professional competency", "social competency", etc., which define large multicomponent systems, subordinate their respective competences as components. It is reasonable to agree with A. Khutorskoy, who defines competence as a set of interrelated personal qualities (knowledge, abilities, skills, ways of activity) set in relation to a certain range of subjects and processes and necessary to act qualitatively and productively in relation to them, and competency as a person's possession of a set of relevant competences, including their personal attitude towards them and the subject of activity. At the same time, N. Bolyubash proposes to divide the competences that make up professional competency into several varieties essential for a particular profession, each of which would contain key competences of one type. Moreover, the professional competency of a specialist should contain several basic types, the number 
and nature of which directly depend on the particular tasks that the specialist has to solve in their professional activity and which allow them to be successful in a particular position.

Thus, comprehension of the competency approach as a methodological tool for the development of professional competency "....as a system, rather than as a set of separate elements of knowledge, skills...", because "... only the system of certain knowledge, skills and other personal qualities allows a person to become a competent specialist", suggests such construction of professional training in art teacher training universities, which directs the mentioned process in the context of this approach to form professional competency of students as an holistic integrative system of competences-components in the areas: pedagogical communication (communicative competency), musical performance (vocal-performance, instrumental-performance competency, etc.), music theory and history (musical-theoretical competency), etc. The development of these component competencies, which are integrated into the content of professional competency, depends in turn on the development of subject competencies according to the courses planned for study in art pedagogical universities.

\section{THE COMPETENCY OF AN ART TEACHER AS A MULTIFACETED CHARACTERISTIC OF THE INDIVIDUAL}

The analysis of scientific-theoretical sources on the competency approach shows that quite often in the scientific literature the application of this approach is not only purposefully linked to the problematic of professional competency development, but is also considered directly in the context of high-quality performance of professional activities. From this perspective, it is appropriate to view the professional competency of an art teacher, art educator as a body of knowledge in art pedagogy, as well as relevant practical skills and experience, allowing it to be conceptualised as a multifaceted characteristic of an individual. This characteristic concerns:

- the personal abilities and personality traits of the music educator;

- his ability to solve problematic situations of art teaching;

- the professional and pedagogical qualities necessary for effective performance of professional functions in art teaching;

- the ability to interact effectively with all subjects of the art learning process based on fluent knowledge and skills in pedagogical and artistic communication necessary for both the purely informative part of art learning and for creatively productive artistic collaboration by providing a positive emotional accompaniment to the learning process;

- the existing system of psychological and pedagogical, art history, musical performance, musical theoretical knowledge, skills and abilities, including knowledge in the field of the motivational and emotional sphere of the individual;

- the ability to act productively based on fundamental knowledge, experience and values; the appropriate quality of professional training based on the state standard of the relevant competency.

The application of the competency approach directs the consideration of professional competency towards the development and intensification of the intellectual and creative potential of future art teachers, art educators and, in particular, mental processes. Indeed, thinking itself is responsible not only for acquiring the knowledge necessary to carry out professional art-pedagogical and art-performance activities, for shaping appropriate skills on this basis, for setting and solving art-pedagogical tasks, but also for assimilating the system of values that underpin art pedagogy. Since the key and important condition of the competency approach methodology is the understanding of competency precisely as a holistic integrative system and not just as a certain set of individual elements of knowledge and skills, it is logical to state that the intellectual basis of professional competency of a future art teacher, art discipline educator is also based on a system - a system of thinking actions and operations, the system of mental actions and operations, that is directly responsible both for the full assimilation of necessary knowledge and for the ability to operate them freely in the process of professional art and pedagogical activity. This system of mental actions and 
operations involves the development of the individual's analytical-synthesising potential, as well as the ability to compare, abstract, generalise, classify, etc. With the help of these mental actions and operations, the future specialist identifies new properties and relations of art education objects, realises their importance for further professional activity, for their own self-development and self-improvement.

At the same time, the development and intensification of the system of mental actions and operations as the fundamental basis for the development of professional competency, promotes the intensification of creative reflection and transformation of reality in the process of art education. Thus, professional competency of a future art teacher, art disciplines educator, actualising full-fledged entry and assimilation of psychological and pedagogical, art history, musical and performance, musical and theoretical knowledge, abilities and skills based on working off the system of mental actions and operations, ability to generalise the accumulated experience of teaching art and abstraction of the content of artistic and pedagogical phenomena, also involves a thorough understanding of the mentioned knowledge, which represents one of the basic functions of the thinking process. Indeed, comprehension is the function that ensures the incorporation of the latest knowledge achievements into the subjective experience of the individual educator.

Further research of professional competency of a future art teacher, art disciplines educator also includes consideration of the phenomenon of artistic and pedagogical erudition, which is based directly on the developed mechanism of mental actions and operations. The development of artistic and pedagogical erudition in pedagogical dimension is ensured by stimulating and activating a complex of mental actions and operations, which, in its turn, allows students not only to create a branched artistic and pedagogical thesaurus as an integrative complex of concepts in art pedagogy, but also makes free operation of the indicated concepts during professional activity. The enrichment of the future art teacher and art educator with knowledge and skills in art pedagogy, music pedagogy and performance, art history, etc. takes place in both empirical and logical ways. Knowledge acquired empirically, which exists in the mind in the form of images and representations, is expressed in the form of empirical concepts. The empirical concepts are acquired by the students while processing the vocal-choral, vocal, instrumental musical works while studying the training courses "Choral conducting", "Choral class", "Methodology of music education", "Voice development", "Special instrument", etc., while studying folk, classical and modern musical art within the courses "National and world music history", "National history and musical folklore of Ukraine", and while attending and participating in concert events, etc. The theoretical knowledge of art history, music pedagogy and psychology, etc., acquired logically, exists in the form of scientific concepts as a reflection of the objectively true in objects or phenomena of art pedagogy.

The authors understand the artistic and pedagogical erudition of future art teachers, art disciplines educators as a broad awareness of art pedagogy, art history, musical psychology, etc., the presence of a complex artistic and pedagogical thesaurus as a branched system of empirical and logical concepts, and the ability to freely operate with these concepts. The established artistic and pedagogical erudition provides for a concentration of empirical and logical concepts by practising them in the process of mental actions and operations of analysis, synthesis, systematisation, classification, comparison and abstraction. The theoretical basis of artistic and pedagogical erudition is laid during the acquisition of art studies and requires the practice of mental operations in all planned activities and types of control, taking into account their conscious execution. The specifics of the methodological support for the teaching of art disciplines are the following: each type of lesson and control involves the application of a maximum number of mental operations. The authors consider oral and written analysis of musical works, creation of annotations for vocal and choral works, comparative analysis of musical works of different genres, etc., characteristics of artistic images, etc. to be very useful. To practise mental operations, the teacher's requirements for students to write essays, reports, messages should include obligatory: analysis, synthesis, comparison, classification, concretisation etc. 


\section{CONCLUSIONS}

Considering the mentioned above, it is reasonable to assert, that the steady tendency on application in art education of the competency-based approach methodology directs the process of art education to the maximum improvement of its quality level by increasing efficiency of knowledge assimilation and acquisition of abilities in the field of the theory and practice of teaching art disciplines, developing artistic and pedagogical thesaurus and appropriate erudition as important factors of forming professional competence of students of art higher education institutions. The intensification of the system of mental actions and operations is a very important basis for its development; it promotes the actualisation of the thinking functions of understanding and the development of logical and empirical concepts. The students' reflective awareness of the development and development of artistic and pedagogical competence is also important, enhancing the mental activity of the individual, intensifying their intellectual development and natural abilities with music simultaneously improving the conceptual apparatus.

The conducted research allowed generalising the definition of professional competency of future art teachers as an integrated qualitative characteristic of an art teacher, which is a complex of knowledge, abilities and skills acquired as a result of professional art training, self-study, own teaching and performing experience in the areas of teaching art disciplines, art history, pedagogy, psychology, etc., and pedagogical and artistic communication, the ability to operate freely with certain knowledge and skills and to apply them effectively in the course of practical professional activities. Thus, the art and pedagogical thesaurus accumulates both intellectual and creative-emotional baggage in the theory and methodology of art education, and the ability to effectively implement this baggage in carrying out professional activities, to apply it precisely, to freely master and operate its logical and empirical concepts based on the developed system of mental actions and operations, indicates the development of artistic and pedagogical erudition one of the most important attributes of the professional competency of future art teachers, art educators.

\section{REFERENCES}

Begić, A., \& Šulentić Begić, J. (2018). Intercultural competence of future music teachers: Social reality and/or need. Sociologija i Prostor, 56(2), 161-178.

Berzinga, D. (2019). Learning by doing. case study: Education for sustainable development at the university of latvia. Periodicals of Engineering and Natural Sciences, 7(1), 156-164.

Bolyubash, N.M. (2009). Theoretical bases of development of professional competence of future economists. Scientific Works: Scientific-Methodical Journal, 99, 88-95.

Burke, J.W. (Ed.). (1989). Competency based education and training. London: Routledge.

Chaikin, O., \& Kirieieva, E. (2020). Branch approach to sustainable development and inclusive growth: Ukraine case. Scientific Horizons, 6(91), 19-25.

Concept of New Ukrainian School. (2016). Retrieved from https://mon.gov.ua/storage/app/media/zagalna\%20serednya/nova-ukrainska-shkolacompressed.pdf

Costello, J., \& Plester, B. (2020). The impact of organisational culture and dynamic capabilities on learning evaluation: An interpretive analysis. International Journal of Learning and Change, 12(4), 476-497.

Delors, J. (1996). Osvita: Prikhovany belongings. Paris: UNESCO.

European Education Foundation. (1997). Glossary of labor market terms, development of standards for educational programs and curricula. Turin: European Training Foundation.

Gavran, I.A., Hutsal, R.S., \& Tsaruk, S.M. (2021). Motivation as a core aspect of the development of professional skills and abilities in the period of distance learning of art students. Scientific

Bulletin of Mukachevo State University. Series "Pedagogy and Psychology", 7(3), 94-101.

Hutmacher, W. (1997). Key competencies for Europe. Strasburg: Council for Cultural Cooperation.

Khomsky, N. (1972). Aspects of syntax theory. Moscow: Moscow University Publishing House. 
Khutorskoy, A.V. (2003). Key competencies as a component of student-centered education. Public Education, 2, 55-60.

Lei, S.Y., Chiu, D.K.W., Lung, M.M-W., \& Chan, C.T. (2021). Exploring the aids of social media for musical instrument education. International Journal of Music Education, 39(2), 187-201.

Pokrova, S.V. (2021). Conceptual model of development of assessment competence of primary school teachers in the system of postgraduate education. Scientific Bulletin of Mukachevo State University. Series "Pedagogy and Psychology", 7(1), 90-102.

Ponomarenko, V.S. (2012). Problems of training competent economists and managers in Ukraine. Kharkiv: VD "INZHEK".

Raven, D. (2002). Competence in modern society: Identification, development and implementation. Moscow: Cogito-Center.

The Verkhovna Rada of Ukraine. (2014). Law of Ukraine "On Higher Education". Retrieved from https://zakon.rada.gov.ua/laws/show/1556-18\#Text

White, R.W. (1959). Motivation reconsidered: The concept of competence. Psychological Review, 66(5), 297-333.

Zimnyaya, I.A. (2004). Key competencies as an effective-target basis of a competence-based approach in education. Moscow: Research Center for the Problems of the Quality of Training of Specialists. 